\title{
Improvement of resource efficiency of the catalytic isomerization process by mathematical modeling
}

\author{
A G Faskhutdinov ${ }^{1}$, I V Akhmetov ${ }^{2}$, A E Musina ${ }^{2}$ and I M Gubaydullin ${ }^{1,2}$ \\ ${ }^{1}$ Institute of Petrochemistry and Catalysis of the Russian Academy of Sciences, Oktyabrya St. \\ 141, Ufa, Russia, 450075 \\ ${ }^{2}$ Ufa State Petroleum Technological University, Kosmonavtov St. 1, Ufa, Russia, 450062
}

\begin{abstract}
The article examines main schemes of reaction networks of the catalytic isomerization of the pentane-hexane fraction. The selection of the kinetic model for the most complete description of the basic chemical processes based on the mechanism of the reactions proceeding is substantiated. The mathematical model is constructed on the basis of kinetic model. The foundations for the subsequent modeling of the entire chemical-technological process system are laid.
\end{abstract}

\section{Introduction}

In connection with the change-over of the domestic oil refining industry to the production of motor gasoline compliant with the Euro- 5 and Euro- 6 standards, the current task is to reduce the content of aromatic hydrocarbons and, in particular, benzene in motor fuel while preserving the octane value. It is known that the main amount of aromatics in motor gasolines is formed in the process of catalytic reforming. Catalytic isomerization of light paraffins, in its turn, makes it possible to obtain a highoctane component of motor gasoline with a minimum content of aromatics. The purpose of the process of catalytic isomerization of the pentane-hexane fraction is the production of high-octane components of automobile gasolines. This process has a high efficiency, because such low-octane oil components as fractions $62-70{ }^{\circ} \mathrm{C}$, as well as catalytic reforming raffinates are used as raw materials. The process is carried out in a hydrogen environment in the presence of bifunctional catalysts [1, 2].

It should be noted that in the postwar years, during the design and construction of most installations, including reactors and devices, inadequate attention has been given to an intensive study of the mechanism of processes. The intensive development of such modern information technologies as parallel computing technology, artificial neural networks (ANN), 3D modeling, simulation modeling, etc., allow us to develop detailed kinetic models of complex processes. Then, based on these models, it is possible to increase significantly the yield of the target product, while minimizing energy and material resources [3].

There are often problems associated with the description of kinetics when studying refining processes. First of all it can be associated with a large component composition of raw materials, as well as the flow of a huge number of chemical reactions taking place on the acid and metal centers of bifunctional catalysts $[4,5]$. In this connection, to simplify the description of the kinetics, the stage of formation of the intermediates that are not present in the composition of the target products is usually not considered. 


\section{Experimental}

The object of the study is the reactor section of the catalytic isomerization unit of the pentane-hexane fraction, consisting of three series reactors. Hydrotreated gasoline fraction with a boiling range of 62$70{ }^{\circ} \mathrm{C}$, containing mainly pentane and hexane was used as a raw material.

The raw material load was $47.6 \mathrm{~m} 3$ / h. Consumption of hydrogen bearing gas (HBG) - 3400 $\mathrm{nm}^{3} / \mathrm{h}$. The composition of the fresh HBG is shown in Table. 1 . The pressure in the reaction zone was 3.2 MPa. The temperatures at the inlet of the first, second and third reactors were 147, 160 and $145^{\circ}$ $\mathrm{C}$, respectively. The temperatures at the outlet of the first, second and third reactors were 160, 170 и $146{ }^{\circ} \mathrm{C}$, respectively. The bifunctional catalyst of the domestic production SI-2 was used as the catalyst of the process. As noted, the reactor unit of the research object consists of three reactors in which the catalyst was distributed at $9,000 \mathrm{~kg}$.

Table 1. The composition of fresh HBG.

\begin{tabular}{lc}
\hline Component & $\begin{array}{c}\text { Mass fraction of } \\
\text { components, \% (GOST } \\
14920)\end{array}$ \\
\hline Nitrogen & 1.44 \\
Hydrogen & 83.61 \\
Isobutane & 0.4 \\
Isopentane & 0.99 \\
Oxygen & 0.58 \\
Methane & 8.18 \\
n-butane & 0.16 \\
n-pentane & 0.14 \\
Propane & 1.06 \\
$\mathrm{C}_{5} \mathrm{H}_{10}$ (sum) & 0.43 \\
Ethane & 3.01 \\
\hline
\end{tabular}

Characteristics of raw materials and product (stable isomerizate) are given in Table. 2 (operation data of the industrial unit for the catalytic isomerization of the pentane-hexane fraction).

Table 2. Characteristics of raw materials and product.

\begin{tabular}{lccc}
\hline & Method & \multicolumn{2}{c}{ Value } \\
\cline { 2 - 4 } Analyzed indicator & & Raw material & Stable isomerate \\
\hline Density at 20 ${ }^{\circ} \mathrm{C}, \mathrm{kg} / \mathrm{m} 3$ & GOST R 51069 & 653.6 & 643.2 \\
Octane number (research method) & GOST 8226 & 67 & 81 \\
Fractional composition, ${ }^{0} \mathrm{C}$ & GOST 2177 & 42 & 36 \\
boiling point & & 62 & 59 \\
$90 \%$ boils away & & 64 & 63 \\
$97 \%$ boils away & & 65 & 64 \\
end of boiling & & 98 & 98 \\
Yield, \% & & & \\
\hline
\end{tabular}

The composition of raw material and product of the catalytic isomerization process of the pentanehexane fraction is given in Table 3 shows (industrial unit data).

It is obvious that for developing a detailed kinetic model it is enough to model only a cascade of reactors. The composition of the gas product mixture after the reactor unit is calculated from the product data after the stabilization unit, that is available. Here it should be noted that with such a calculation, the indicators of productive flows have a large effect on the final result.

In such cases, the instruments error can reach 5\% for flows in the gaseous state and 3\% for the flows in the liquid state. Therefore, the use of such data without preliminary verification (balance on carbon and hydrogen) is absolutely unacceptable. 
Table 3. The composition of raw material and product.

\begin{tabular}{lcc}
\hline & Raw material, \% weight & Isomerizate, \% weight \\
\hline Component & & 21.13 \\
2,3- DMB & 0.36 & 6.57 \\
2-MP & 2.15 & 19.58 \\
3-MP & 19.32 & 11.23 \\
Benzene & 14.73 & - \\
Isopentane & 1.25 & 23.56 \\
Methylcyclopentane & 10.75 & 0.12 \\
N-hexane & 2.7 & 7.27 \\
N-pentane & 18.19 & 7.80 \\
Isobutane & 30.81 & 1.04 \\
N-butane & - & 0.87 \\
Propane & - & 0.61 \\
Ethane & - & 0.13 \\
Methane & - & 0.09 \\
\hline
\end{tabular}

where 2-MP - 2-methylpentane, 3-MP - 3-methylpentane, 2.2-DMB - 2.2-dymethylbutane, 2.3-DMB - 2.3-methylbutane.

\section{Scheme of reaction networks of the catalytic isomerization of the pentane-hexane fraction}

The first stage of the mathematical description of the object is the scheming of hydrocarbon reactions during the process. It should be noted that the accuracy of calculations and the adequacy of the mathematical model to the actual process directly depend on the degree of detail of chemical transformations. Therefore, the transformation scheme should sufficiently reflect the physico-chemical nature of the process $[6,7]$.

In this article there was an attempt to make more detailed analysis of the scheme of reaction networks proceeding from the mechanism.

It is known that reactions in the process of isomerization in the presence of bifunctional catalysts proceed along the carbon-ion mechanism [8-10]. The thermodynamics of the process is the basis. The result of thermodynamic analysis is a list of reactions that probably proceed under given conditions $[11,12]$. The probability of reactions under the process conditions of the catalytic isomerization of the pentane-hexane fraction (temperature- $150{ }^{\circ} \mathrm{C}(423 \mathrm{~K})$ and pressure-3.2 MPa) was estimated from the value of Gibbs energy $\Delta \mathrm{G}$ (Table 4 ).

From the Table 4 we can see that isomerization, dehydrocyclization, naphthene conversion, dehydrogenating reactions are reversible. Whereas hydrocracking reactions are irreversible [13].

According to the equations of reactions taking place in the process of catalytic isomerization of the pentane-hexane fraction, we write the kinetic equations as follows (Table 5).

Table 4. The reaction equations for the catalytic isomerization of the pentane-hexane fraction and the values of the thermodynamic characteristics.

\begin{tabular}{cccc}
\hline & Reaction & $\Delta \mathrm{H}, \mathrm{kJ} / \mathrm{mol}$ & $\Delta \mathrm{G}, \mathrm{kJ} / \mathrm{mol}$ \\
\hline 1. & $\mathrm{n}-\mathrm{C}_{5} \mathrm{H}_{12} \leftrightarrow \mathrm{i}-\mathrm{C}_{5} \mathrm{H}_{12}$ & -8.22 & -5.76 \\
2. & $\mathrm{n}-\mathrm{C}_{6} \mathrm{H}_{14} \leftrightarrow 2-\mathrm{MP}$ & -6.98 & -3.77 \\
3. & $\mathrm{n}-\mathrm{C}_{6} \mathrm{H}_{14} \leftrightarrow 3-\mathrm{MP}$ & -4.44 & -7.60 \\
4. & $\mathrm{n}-\mathrm{C}_{6} \mathrm{H}_{14} \leftrightarrow 2.2-\mathrm{DMB}$ & -18.53 & -5.60 \\
5. & $\mathrm{n}-\mathrm{C}_{6} \mathrm{H}_{14} \leftrightarrow 2.3-\mathrm{DMB}$ & -10.93 & -0.99 \\
6. & $2-\mathrm{MP} \leftrightarrow 3-\mathrm{MP}$ & -2.54 & -3.02 \\
7. & $2.2-\mathrm{DMB} \leftrightarrow 2.3-\mathrm{DMB}$ & -7.61 & -4.61 \\
8. & $\mathrm{BZ}+\mathrm{H}_{2} \leftrightarrow \mathrm{CH}$ & -213.94 & -52.65 \\
9. & $\mathrm{BZ}+\mathrm{H}_{2} \leftrightarrow \mathrm{MCP}$ & -197.03 & -53.83 \\
10. & $\mathrm{CH} \leftrightarrow \mathrm{MCP}$ & -112.34 & 49.10 \\
11. & $\mathrm{n}-\mathrm{C}_{6} \mathrm{H}_{14} \leftrightarrow \mathrm{CH}+\mathrm{H}_{2}$ & 8.57 & 7.82 \\
12. & $2-\mathrm{MP} \leftrightarrow \mathrm{MCP}+\mathrm{H}_{2}$ & -66.96 & -29.59
\end{tabular}




\begin{tabular}{|c|c|c|c|}
\hline 13. & $3-\mathrm{MP} \leftrightarrow \mathrm{MCP}+\mathrm{H}_{2}$ & -64.42 & -26.58 \\
\hline 14. & 2.2-DMB $\leftrightarrow \mathrm{MCP}+\mathrm{H}_{2}$ & -78.51 & -31.43 \\
\hline 15. & 2.3-DMB $\leftrightarrow \mathrm{MCP}+\mathrm{H}_{2}$ & -70.91 & -26.82 \\
\hline 16. & $\mathrm{MCP}+\mathrm{H}_{2} \rightarrow 3-\mathrm{MP}$ & -64.42 & -26.58 \\
\hline 17. & $\mathrm{n}-\mathrm{C}_{5} \mathrm{H}_{12}+\mathrm{H}_{2} \rightarrow \mathrm{C}_{3} \mathrm{H}_{8}+\mathrm{C}_{2} \mathrm{H}_{6}$ & -44.49 & -49.96 \\
\hline 18. & $\mathrm{n}-\mathrm{C}_{5} \mathrm{H}_{12}+\mathrm{H}_{2} \rightarrow \mathrm{n}-\mathrm{C}_{4} \mathrm{H}_{10}+\mathrm{CH}_{4}$ & -56.57 & -61.66 \\
\hline 19. & $\mathrm{n}-\mathrm{C}_{6} \mathrm{H}_{14}+\mathrm{H}_{2} \rightarrow 2 \mathrm{C}_{3} \mathrm{H}_{8}$ & -37.94 & -48.88 \\
\hline 20. & $\mathrm{n}-\mathrm{C}_{6} \mathrm{H}_{14}+\mathrm{H}_{2} \rightarrow \mathrm{n}-\mathrm{C}_{4} \mathrm{H}_{10}+\mathrm{C}_{2} \mathrm{H}_{6}$ & -45.91 & -51.80 \\
\hline 21. & $\mathrm{n}-\mathrm{C}_{6} \mathrm{H}_{14}+\mathrm{H}_{2} \rightarrow \mathrm{n}-\mathrm{C}_{5} \mathrm{H}_{12}+\mathrm{CH}_{4}$ & -56.14 & -47.34 \\
\hline 22. & $\mathrm{n}-\mathrm{C}_{6} \mathrm{H}_{14}+\mathrm{H}_{2} \rightarrow \mathrm{i}-\mathrm{C}_{5} \mathrm{H}_{12}+\mathrm{CH}_{4}$ & -64.35 & -66.71 \\
\hline 23. & $2-\mathrm{MP}+\mathrm{H}_{2} \rightarrow \mathrm{i}-\mathrm{C}_{4} \mathrm{H}_{10}+\mathrm{C}_{2} \mathrm{H}_{6}$ & -47.38 & -49.82 \\
\hline 24. & $3-\mathrm{MP}+\mathrm{H}_{2} \rightarrow \mathrm{i}-\mathrm{C}_{5} \mathrm{H}_{12}+\mathrm{CH}_{4}$ & -59.91 & -65.95 \\
\hline 25. & 2.3-DMB $+\mathrm{H}_{2} \rightarrow \mathrm{i}-\mathrm{C}_{4} \mathrm{H}_{10}+\mathrm{C}_{2} \mathrm{H}_{6}$ & -43.44 & -52.63 \\
\hline 26. & 2.3-DMB $+\mathrm{H}_{2} \rightarrow \mathrm{i}-\mathrm{C}_{5} \mathrm{H}_{12}+\mathrm{CH}_{4}$ & -53.43 & -65.71 \\
\hline 27. & $\mathrm{i}-\mathrm{C}_{5} \mathrm{H}_{12}+\mathrm{H}_{2} \rightarrow \mathrm{i}-\mathrm{C}_{4} \mathrm{H}_{10}+\mathrm{CH}_{4}$ & -56.82 & -57.71 \\
\hline 28. & 2.2-DMB $+\mathrm{H}_{2} \rightarrow \mathrm{i}-\mathrm{C}_{4} \mathrm{H}_{10}+\mathrm{C}_{2} \mathrm{H}_{6}$ & -35.83 & -48.05 \\
\hline 29. & 2.2-DMB $+\mathrm{H}_{2} \rightarrow \mathrm{i}-\mathrm{C}_{5} \mathrm{H}_{12}+\mathrm{CH}_{4}$ & -45.82 & -61.11 \\
\hline
\end{tabular}

where 2-MP - 2-methylpentane, 3-MP - 3-methylpentane, 2.2-DMB - 2.2-dymethylbutane, 2.3-DMB - 2.3-methylbutane, $\mathrm{CH}$ - cyclohexane, MCP - methylcyclopentane, BZ - benzene.

Table 5. Kinetic equations of the process of catalytic isomerization of pentane-hexane fraction.

\begin{tabular}{|c|c|c|}
\hline & Reaction & Kinetic equations \\
\hline 1. & $\mathrm{n}-\mathrm{C}_{5} \mathrm{H}_{12} \leftrightarrow \mathrm{i}-\mathrm{C}_{5} \mathrm{H}_{12}$ & $\mathrm{~W}_{1}=\mathrm{k}_{1} * \mathrm{x}_{1}-\mathrm{k}_{2} * \mathrm{x}_{2}$ \\
\hline 2. & $\mathrm{n}-\mathrm{C}_{6} \mathrm{H}_{14} \leftrightarrow 2-\mathrm{MP}$ & $\mathrm{W}_{2}=\mathrm{k}_{3} * \mathrm{x}_{3}-\mathrm{k}_{4} * \mathrm{x}_{4}$ \\
\hline 3. & $\mathrm{n}-\mathrm{C}_{6} \mathrm{H}_{14} \leftrightarrow 3-\mathrm{MP}$ & $\mathrm{W}_{3}=\mathrm{k}_{5} * \mathrm{x}_{3}-\mathrm{k}_{6} * \mathrm{x}_{5}$ \\
\hline 4. & $\mathrm{n}-\mathrm{C}_{6} \mathrm{H}_{14} \leftrightarrow 2,2-\mathrm{DMB}$ & $\mathrm{W}_{4}=\mathrm{k}_{7} * \mathrm{x}_{3}-\mathrm{k}_{8} * \mathrm{x}_{6}$ \\
\hline 5. & $\mathrm{n}-\mathrm{C}_{6} \mathrm{H}_{14} \leftrightarrow 2,3-\mathrm{DMB}$ & $\mathrm{W}_{5}=\mathrm{k}_{9} * \mathrm{x}_{3}-\mathrm{k}_{10} * \mathrm{x}_{7}$ \\
\hline 6. & 2-MP $\leftrightarrow 3-\mathrm{MP}$ & $\mathrm{W}_{6}=\mathrm{k}_{11} * \mathrm{x}_{4}-\mathrm{k}_{12} * \mathrm{x}_{5}$ \\
\hline 7. & 2.2-DMB $\leftrightarrow 2.3-\mathrm{DMB}$ & $\mathrm{W}_{7}=\mathrm{k}_{13} * \mathrm{x}_{6}-\mathrm{k}_{14} * \mathrm{x}_{7}$ \\
\hline 8. & $\mathrm{BZ}+\mathrm{H}_{2} \leftrightarrow \mathrm{CH}$ & $\mathrm{W}_{8}=\mathrm{k}_{15} * \mathrm{x}_{8} * \mathrm{x}_{9}{ }^{3}-\mathrm{k}_{16} * \mathrm{x}_{10}$ \\
\hline 9. & $\mathrm{BZ}+\mathrm{H}_{2} \leftrightarrow \mathrm{MCP}$ & $\mathrm{W}_{9}=\mathrm{k}_{17} * \mathrm{x}_{8} * \mathrm{x}_{9}{ }^{3}-\mathrm{k}_{18} * \mathrm{x}_{11}$ \\
\hline 10. & $\mathrm{CH} \leftrightarrow \mathrm{MCP}$ & $\mathrm{W}_{10}=\mathrm{k}_{19} * \mathrm{x}_{10}-\mathrm{k}_{20} * \mathrm{x}_{11}$ \\
\hline 11. & $\mathrm{n}-\mathrm{C}_{6} \mathrm{H}_{14} \leftrightarrow \mathrm{CH}+\mathrm{H}_{2}$ & $\mathrm{~W}_{11}=\mathrm{k}_{21} * \mathrm{x}_{3}-\mathrm{k}_{22} * \mathrm{x}_{10} * \mathrm{x}_{9}$ \\
\hline 12. & $2-\mathrm{MP} \leftrightarrow \mathrm{MCP}+\mathrm{H}_{2}$ & $\mathrm{~W}_{12}=\mathrm{k}_{23}{ }^{*} \mathrm{x}_{4}-\mathrm{k}_{23}{ }^{*} \mathrm{x}_{11}{ }^{*} \mathrm{x}_{9}$ \\
\hline 13. & $3-\mathrm{MP} \leftrightarrow \mathrm{MCP}+\mathrm{H}_{2}$ & $\mathrm{~W}_{13}=\mathrm{k}_{25}{ }^{*} \mathrm{x}_{5}-\mathrm{k}_{26}{ }^{*} \mathrm{x}_{11}{ }^{*} \mathrm{x}_{9}$ \\
\hline 14. & 2.2-DMB $\leftrightarrow \mathrm{MCP}+\mathrm{H}_{2}$ & $\mathrm{~W}_{14}=\mathrm{k}_{27} * \mathrm{x}_{6}-\mathrm{k}_{28} * \mathrm{x}_{11} * \mathrm{x}_{9}$ \\
\hline 15. & 2.3-DMB $\leftrightarrow \mathrm{MCP}+\mathrm{H}_{2}$ & $\mathrm{~W}_{15}=\mathrm{k}_{29}{ } \mathrm{x}_{7}-\mathrm{k}_{30}{ }^{*} \mathrm{x}_{11}{ }^{*} \mathrm{x}_{9}$ \\
\hline 16. & $\mathrm{MCP}+\mathrm{H}_{2} \rightarrow 3-\mathrm{MP}$ & $\mathrm{W}_{16}=\mathrm{k}_{31} * \mathrm{x}_{11} * \mathrm{x}_{9}$ \\
\hline 17. & $\mathrm{n}-\mathrm{C}_{5} \mathrm{H}_{12}+\mathrm{H}_{2} \rightarrow \mathrm{C}_{3} \mathrm{H}_{8}+\mathrm{C}_{2} \mathrm{H}_{6}$ & $\mathrm{~W}_{17}=\mathrm{k}_{32} * \mathrm{x}_{1} * \mathrm{x}_{9}$ \\
\hline 18. & $\mathrm{n}-\mathrm{C}_{5} \mathrm{H}_{12}+\mathrm{H}_{2} \rightarrow \mathrm{n}-\mathrm{C}_{4} \mathrm{H}_{10}+\mathrm{CH}_{4}$ & $\mathrm{~W}_{18}=\mathrm{k}_{33} * \mathrm{x}_{1} * \mathrm{x}_{9}$ \\
\hline 19. & $\mathrm{n}-\mathrm{C}_{6} \mathrm{H}_{14}+\mathrm{H}_{2} \rightarrow 2 \mathrm{C}_{3} \mathrm{H}_{8}$ & $\mathrm{~W}_{19}=\mathrm{k}_{34} * \mathrm{x}_{3} * \mathrm{x}_{9}$ \\
\hline 20. & $\mathrm{n}-\mathrm{C}_{6} \mathrm{H}_{14}+\mathrm{H}_{2} \rightarrow \mathrm{n}-\mathrm{C}_{4} \mathrm{H}_{10}+\mathrm{C}_{2} \mathrm{H}_{6}$ & $\mathrm{~W}_{20}=\mathrm{k}_{35} * \mathrm{x}_{3} * \mathrm{x}_{9}$ \\
\hline 21. & $\mathrm{n}-\mathrm{C}_{6} \mathrm{H}_{14}+\mathrm{H}_{2} \rightarrow \mathrm{n}-\mathrm{C}_{5} \mathrm{H}_{12}+\mathrm{CH}_{4}$ & $\mathrm{~W}_{21}=\mathrm{k}_{36} * \mathrm{x}_{3} * \mathrm{x}_{9}$ \\
\hline 22. & $\mathrm{n}-\mathrm{C}_{6} \mathrm{H}_{14}+\mathrm{H}_{2} \rightarrow \mathrm{i}-\mathrm{C}_{5} \mathrm{H}_{12}+\mathrm{CH}_{4}$ & $\mathrm{~W}_{22}=\mathrm{k}_{37} * \mathrm{x}_{3}{ }^{*} \mathrm{x}_{9}$ \\
\hline 23. & $2-\mathrm{MP}+\mathrm{H}_{2} \rightarrow \mathrm{i}-\mathrm{C}_{4} \mathrm{H}_{10}+\mathrm{C}_{2} \mathrm{H}_{6}$ & $\mathrm{~W}_{23}=\mathrm{k}_{38} * \mathrm{x}_{4} * \mathrm{x}_{9}$ \\
\hline 24. & $3-\mathrm{MP}+\mathrm{H}_{2} \rightarrow \mathrm{i}-\mathrm{C}_{5} \mathrm{H}_{12}+\mathrm{CH}_{4}$ & $\mathrm{~W}_{24}=\mathrm{k}_{39} * \mathrm{x}_{5} * \mathrm{x}_{9}$ \\
\hline 25. & 2.3-DMB $+\mathrm{H}_{2} \rightarrow \mathrm{i}-\mathrm{C}_{4} \mathrm{H}_{10}+\mathrm{C}_{2} \mathrm{H}_{6}$ & $\mathrm{~W}_{25}=\mathrm{k}_{40} * \mathrm{x}_{7} * \mathrm{x}_{9}$ \\
\hline 26. & 2.3-DMB $+\mathrm{H}_{2} \rightarrow \mathrm{i}-\mathrm{C}_{5} \mathrm{H}_{12}+\mathrm{CH}_{4}$ & $\mathrm{~W}_{26}=\mathrm{k}_{41} * \mathrm{x}_{7} * \mathrm{x}_{9}$ \\
\hline 27. & $\mathrm{i}-\mathrm{C}_{5} \mathrm{H}_{12}+\mathrm{H}_{2} \rightarrow \mathrm{i}-\mathrm{C}_{4} \mathrm{H}_{10}+\mathrm{CH}_{4}$ & $\mathrm{~W}_{27}=\mathrm{k}_{42} * \mathrm{x}_{2} * \mathrm{x}_{9}$ \\
\hline 28. & 2.2-DMB $+\mathrm{H}_{2} \rightarrow \mathrm{i}-\mathrm{C}_{4} \mathrm{H}_{10}+\mathrm{C}_{2} \mathrm{H}_{6}$ & $\mathrm{~W}_{28}=\mathrm{k}_{43} * \mathrm{x}_{6} * \mathrm{x}_{9}$ \\
\hline 29. & 2.2-DMB $+\mathrm{H}_{2} \rightarrow \mathrm{i}-\mathrm{C}_{5} \mathrm{H}_{12}+\mathrm{CH}_{4}$ & $\mathrm{~W}_{29}=\mathrm{k}_{44} * \mathrm{x}_{6} * \mathrm{x}_{9}$ \\
\hline
\end{tabular}

where $x_{i}-$ concentration of components in mole fractions, $x_{1}-n$-pentane, $x_{2}-$ isopentane, $x_{3}-n-$ hexane, $x_{4}-2-M P, x_{5}-3-M P, x_{6}-2,2-D M B, x_{7}-2,3-D M B, x_{8}-$ benzene, $x_{9}-$ hydrogen, $x_{10}-$ cyclohexane, $x_{11}$ - methylcyclopentane, $x_{12}$ - propane, $x_{13}$ - ethane, $x_{14}-H$-butane, $x_{15}$ - methane, $x_{16}$ 
- isobutane, $k_{j}$ - kinetic constant of the $j$-th reaction, $L \cdot \mathrm{mol}^{-1} \cdot h^{-1}(j=8,9,11-29), h^{-1}(j=1-7,10), W_{j}-$ rate of the $\mathrm{j}$-th reaction, $\mathrm{mol} /(\mathrm{l} \cdot \mathrm{h})$.

The reaction rates entering into the kinetic model (Table 5) were written according to the law of mass action [14]. The mathematical model of the process is a system of nonlinear differential equations $[15,16]$ :

$$
\begin{aligned}
& \int \frac{d x_{1}}{d t}=-W_{1}-W_{17}-W_{18}+W_{21} \\
& \frac{d x_{2}}{d t}=W_{1}+W_{22}+W_{23}+W_{24}+W_{26}-W_{27}+W_{29} \\
& \frac{d x_{3}}{d t}=-W_{2}-W_{3}-W_{4}-W_{5}-W_{11}-W_{19}-W_{20}-W_{21}-W_{22} \\
& \frac{d x_{4}}{d t}=W_{2}-W_{6}-W_{12}-W_{23} \\
& \frac{d x_{5}}{d t}=W_{3}+W_{6}-W_{13}+W_{16}-W_{24} \\
& \frac{d x_{6}}{d t}=W_{4}-W_{7}-W_{14}-W_{28}-W_{29} \\
& \frac{d x_{7}}{d t}=W_{5}+W_{7}-W_{15}-W_{25}-W_{26} \\
& \frac{d x_{8}}{d t}=-W_{8}-W_{9} \\
& \left\{\frac{d x_{9}}{d t}=-3 W_{8}-3 W_{9}+W_{11}+W_{12}+W_{13}+W_{14}+W_{15}-W_{16}-W_{17}-W_{18}-W_{19}-W_{20}-\right. \\
& -W_{21}-W_{22}-W_{23}-W_{24}-W_{25}-W_{26}-W_{27}-W_{28}-W_{29} \\
& \frac{d x_{10}}{d t}=W_{8}-W_{10}+W_{11} \\
& \frac{d x_{11}}{d t}=W_{9}+W_{10}+W_{12}+W_{13}+W_{14}+W_{15}-W_{16} \\
& \frac{d x_{12}}{d t}=W_{17}+2 W_{19} \\
& \frac{d x_{13}}{d t}=W_{17}+W_{25}+W_{27}+W_{28} \\
& \frac{d x_{14}}{d t}=W_{18} \\
& \frac{d x_{15}}{d t}=W_{18}+W_{21}+W_{22}+W_{23}+W_{24}+W_{26}+W_{29} \\
& \frac{d x_{16}}{d t}=W_{25}+W_{27}+W_{28}
\end{aligned}
$$

With initial conditions $\mathrm{t}=0, \mathrm{x}_{\mathrm{i}}(0)=\mathrm{x}_{\mathrm{i}, 0}$, where $\mathrm{i}$ - corresponding hydrocarbon.

Thus, the dimension of the system of a mathematical model equations is coincides with the number of substances whose concentration is determined in calculations.

To apply the obtained model, it is first necessary to make a comparative assessment of the kinetic parameters.

When solving the inverse kinetic task, it is planned to use the method of parabolic descent. It is also planned to use a modified Kutta-Merson method of the fifth order of accuracy to solve the system of ordinary nonlinear differential equations [17]. 
The solution algorithm of a system of differential equations $\frac{d x}{d t}=f(x)$ requires a fivefold calculation of the right-hand sides $\mathrm{f}(\mathrm{x})[18]$ :

$$
\begin{gathered}
\mathrm{F}_{1}=\mathrm{f}\left(\mathrm{x}_{\mathrm{k}}\right) \cdot \mathrm{h}, \\
\mathrm{F}_{2}=\mathrm{f}\left(\mathrm{x}_{\mathrm{k}}+\mathrm{F}_{1} / 3\right) \cdot \mathrm{h}, \\
\mathrm{F}_{3}=\mathrm{f}\left(\mathrm{x}_{\mathrm{k}}+\left(\mathrm{F}_{1}+\mathrm{F}_{2}\right) / 6\right) \cdot \mathrm{h}, \\
\mathrm{F}_{4}=\mathrm{f}\left(\mathrm{x}_{\mathrm{k}}+\left(\mathrm{F}_{1}+3 \cdot \mathrm{F}_{2}\right) / 8\right) \cdot \mathrm{h}, \\
\mathrm{x}_{\mathrm{k}+1}=\mathrm{x}_{\mathrm{k}}+\left(\mathrm{F}_{1}-3 \cdot \mathrm{F}_{2}+4 \cdot \mathrm{F}_{4}\right) / 2, \\
\mathrm{~F}_{5}=\mathrm{f}\left(\mathrm{x}_{\mathrm{k}+1}\right) \cdot \mathrm{h}, \\
\mathrm{x}_{\mathrm{k}+1}^{*}=\mathrm{x}_{\mathrm{k}}+\left(\mathrm{F}_{1}+4 \cdot \mathrm{F}_{4}+\mathrm{F}_{5}\right),
\end{gathered}
$$

where $\mathrm{h}$ - step of integration over a spatial or temporal coordinate, $\mathrm{x}_{\mathrm{k}}$ - values of variables at the beginning of the integration interval. At the end of the integration interval, two solutions are obtained: $\mathrm{x}_{\mathrm{k}+1}$ - by the Runge-Kutta method with accuracy $\mathrm{O}\left(\mathrm{h}^{4}\right)$ and $\mathrm{X}_{\mathrm{k}+1}^{*}$ - by the Kutta-Merson method with accuracy $\mathrm{O}\left(\mathrm{h}^{5}\right)$.

\section{Findings}

- With the help of calculations, it has been shown that all reactions occurring in the transformation scheme is probable from the point of view of thermodynamics under the conditions of the process.

- The detailed mathematical model is proposed, consisting in consideration of all components of the raw material fraction with the boiling range of $62-70^{\circ} \mathrm{C}$ (pentane-hexane fraction).

\section{Conclusion}

Development on the basis of the reaction mechanism of an adequate kinetic model is an important stage in the creating of a mathematical model. Due to the fact that by solving inverse kinetic tasks, the parameters that will serve as the basis for the mathematical model are determined, and also taking into account physicochemical aspects of the process, the mathematical model will allow to carry out predicted calculations, to select the optimal technological conditions for increasing the resource efficiency of the catalytic isomerization process of pentane-hexane faction.

\section{References}

[1] Ahmetov S A 2002 Technology of advanced oil and gas refining (Ufa: Gilem) p 672

[2] Koncsa C I, Tutun I and Safta C 2011 Study of C5/C6 isomerization on Pt/H-zeolite catalyst in industrial conditions Ovidius Univ. Annal. Chem. 22 102-106

[3] Bursian N R 1985 Technology of isomerization of paraffinic hydrocarbons (Moscow: Chemistry) p 192

[4] Stijepovic M Z, Ostojic A V, Milenkovic I and Linke P 2009 Development of a kinetic model for catalytic reforming of naphtha and parameter estimation using industrial plant data Energy Fuels 23 979-983

[5] Ismagilov I Z, Matus E V, Nefedova D V, Kuznetcov V V, Yashnik S A, Kerzhentcev M A and Ismagilov Z R 2015 Effect of support modification on the physicochemical properties of a $\mathrm{NiPd} / \mathrm{Al}_{2} \mathrm{O}_{3}$ catalyst for the autothermal reforming of methane Kinetics and Catalysis 56397

[6] Belinskaya N S, Silko G U, Frantcina E V, Ivashkina E N and Ivanchina E D 2013 Development of a formalized scheme for the transformation of hydrocarbons and the kinetic model of the process of hydrodewaxing diesel fuels Bulletin of the Tomsk Polytechnic University 322 129-133

[7] Chuzlov V A, Ivanchina E D, Dolganov I M and Molotov K V 2015 Simulation of light naphtha isomerization process Procedia Chemistry 15 282-287

[8] Barron Y, Maire G, Muller J M and Gault F G 1966 The mechanisms of hydrogenolysis and isomerization of hydrocarbons on metals Journal of Catalysis 5 428-445 
[9] Ono Y 2003 A survey of the mechanism in catalytic isomerization of alkanes Catal. Today 81 316

[10] Liu H, Meng X, Zhang R, Liu Z, Meng J and Xu C 2010 Reaction performance and disappearance kinetics of n-pentane isomerization catalyzed by chloroaluminate ionic liquid Catal. Commun 12 180-183

[11] Dymond J H, Young K J and Isdale J D 1979 Chem. Thermodyn. p 887

[12] Maginn E J, Theodorou D N and Bell A T 1995 Sorption thermodynamics, siting and conformation of long n-alkanes in silicalite as predicted by configurational-bias Monte Carlo integration Phys. Chem. 99 2057-2079

[13] Triwahyono S, Jalil A A, Mukti R R, Musthofa M, Razali N A M and Aziz M A A 2011 Hydrogen spillover behavior of Zn/HZSM-5 showing catalytically active protonic acid sites in the isomerization of n-pentane Appl. Catal. (A: Gen) 407 91-99

[14] Khusnutdinov R I, Baiguzina A R, Mukminov R R, Akhmetov I V, Gubaidullin I M, Spivak S I and Dzhemilev U M 2010 New synthesis of pyrrole-2-carboxylic and pyrrole-2,5- dicarboxylic acid esters in the presence of iron-containing catalysts Russian Journal of Organic Chemistry $\mathbf{4 6}$ 1053-1059

[15] Koledina K F and Gubaydullin I M 2016 Kinetics and mechanism of olefin catalytic hydroalumination by organoaluminum compounds Zhurnal fizicheskoi khimii 90 671-678

[16] Gubaydullin I M, Koledina K F and Lind Yu B 2011 Modern high-performance computing technologies for modeling the detailed mechanism for the reaction of catalytic hydroalumination of olefins Nauka I obrazovanie: nauchnoe izdanie MGTU im. N.E. Bauman 610

[17] Akhmetov I V and Gubaydullin I M 2016 Analysis of methods for solving inverse problems of chemical kinetics with the use of parallel computing CEUR Workshop Proceedings 1576 402-410

[18] Akhmetov I V and Gubaydullin I M 2017 Parallel calculations in the construction of the kinetic model of benzylidene benzylamine synthesis CEUR Workshop Proceedings 1902 1-4 